\title{
Effect of dormancy breaking chemicals on microtuber production potential under in vivo conditions of central India
}

\author{
Murlidhar J. Sadawarti ${ }^{*}$, K. K. Pandey ${ }^{3}$, R. K. Samadhiya ${ }^{1}$, Y. P. Singh ${ }^{1}$, R. K. Singh ${ }^{2}$, \\ S. P. Singh ${ }^{1}$ and S. Roy ${ }^{1}$
}

${ }^{1}$ ICAR-Central Potato Research Station, Gwalior-474006 (Madhya Pradesh), INDIA

${ }^{2}$ ICAR-Central Potato Research Institute, Shimla-171001 (Himachal Pradesh), INDIA

${ }^{3}$ ICAR-Indian Institute of Vegetable Research, Varanasi- 221305 (Uttar Pradesh), INDIA

*Corresponding author. E-mail: murlidharsada@gmail.com

Received: December 6, 2016; Revised received: May 30, 2017; Accepted: October 5, 2017

\begin{abstract}
The present study was carried out at ICAR -Central Potato Research Station, Gwalior during 2012-13 to assess the effect of dormancy breaking chemicals, their dip duration and microtuber size on growth and yield parameters. The three different size $>4-6 \mathrm{~mm},>6-8 \mathrm{~mm}$ and $>8 \mathrm{~mm}$ of variety Kufri Sindhuri were given dip treatment with six types of growth regulators/ dormancy breaking chemicals viz $1 \mathrm{ppm}$ gibberelic acid, $0.5 \mathrm{ppm}$ gibberllic acid, $1 \%$ thiourea, $0.5 \%$ thiourea, $1 \mathrm{ppm}$ gibberllic acid $+1 \%$ thiourea and $0.5 \mathrm{ppm}$ gibberllic acid $+0.5 \%$ thiourea along with water control for $30 \mathrm{~min}, 45 \mathrm{~min}$ and $60 \mathrm{~min}$. All the treatments exhibited better growth and yield parameters over water control but significantly best at $5 \%$ was $0.5 \mathrm{ppm}$ gibberllic acid treatment for growth parameters and 0.5 ppm gibberllic acid $+0.5 \%$ thiourea treatment for yield parameters. All the dip duration $30 \mathrm{~min}, 45 \mathrm{~min}$ and $60 \mathrm{~min}$ had not significant at $5 \%$ level effect for both growth and yield parameters. The larger sized micro-tuber (>8 mm) showed significantly superior plant emergence, plant height, number of compound leaves per plant, number of stems per plant both at 50 and 75 days after planting followed by $4-8 \mathrm{~mm}$ grade and $<4 \mathrm{~mm}$ grade micro-tubers. Similar trend was observed for all the yield parameters. The overall mean finding indicates that micro-tubers treated with $0.5 \mathrm{ppm}$ gibberllic acid in combination with $0.5 \%$ thiourea gave highest yield ( $226.0 \mathrm{q} / \mathrm{ha}$ tuber), among microtuber size of $>8 \mathrm{~mm}$ (295.0 q/ha tuber) and among dip duration $30 \mathrm{~min}(206.67 \mathrm{q} / \mathrm{ha})$ and $45 \mathrm{~min}(210 \mathrm{q} / \mathrm{ha}) \mathrm{resulted}$ in significantly higher yield parameters under nucleus seed production in in vivo conditions of central India.
\end{abstract}

Keywords: Dormancy breaking chemicals, In vivo condition, Microtuber, Yield

\section{INTRODUCTION}

Microtubers are produced in vitro in a plethora of different growing systems with varying environment, media constituents, and storage intervals. Accordingly, microtubers come in different sizes, have different dormancy requirements, and differ widely in relative growth potential and productivity (Badoni and Chauhan, 2009). The tubers falling in between 4.0 and $6.0 \mathrm{~mm}$ considered as small, $6.1-8.0 \mathrm{~mm}$ as medium and above $8.1 \mathrm{~mm}$ as large. The average fresh weight of small, medium, and large microtubers were 0.18 , 0.29 , and $0.54 \mathrm{~g}$, respectively (Park et al., 2009). Microtubers with $3 \mathrm{~g}$ weight sprout after 10 days, while microtubers with 375 and $750 \mathrm{mg}$ sprout after 15 and 13 days respectively indicating dormancy requirement varies with size of the microtuber (Struik and Lommen., 1999). Microtubers can be used in the net house to produce minitubers in Generation- 0 or they can be used directly in the field for nucleus seed production generation-1 in potato. In the micro-tuber based seed potato production system, about $30-40 \%$ micro-tubers are lost during storage (due to drying and rottage) and the emergence of remaining micro-tubers is only 45$50 \%$ (Venkatasalam et al., 2011). The function of minitubers resulting from microtubers is affected by many factors like species, microtuber size and length of its dormancy (Bolandi et al., 2011).

Minitubers dormancy period can be removed by setting the store temperature, cutting the tubers, and treating by chemicals. Treating minitubers with chemicals is a safe and confident method. Among the chemicals applied for breaking down the potato nodes dormancy, one can refer to $\mathrm{GA}_{3}$, thiourea, ethylene, ethyl bromide, and carbon disulphide (Otroshy and Struik, 2006). Thiourea treatment is not only more efficient to break dormancy but it increases also sprouts number, comparing to other chemicals (IAA and $\mathrm{GA}_{3}$ ) (Germchi et al., 2010). In addition, thiourea has great influence on yield and quality of potato tubers (Panah et al., 2007). Hassan-Panah et al (2007) reported a concentration of $1500 \mathrm{ppm}$ and $5 \%$ thiourea to break dormancy and decreases dormancy period but showed that the tuber yield and its weight per plant declined after sowing seeds in the greenhouse

Components like micro-tubers tuber size, physiological 
age, green sprouting methods, size grading and crop husbandry techniques affect tuber yield (Struik and Lommen, 1999). Microtuber using about 250-500 mg size is the best for maximizing minituber yield compared to plantlet may be a feasible practice under the field condition (Hossain et al., 2017). All the grades of micro-tubers ( $<4 \mathrm{~mm}, 4-8 \mathrm{~mm}$ and $>8 \mathrm{~mm}$ ) of both the varieties Kufri Megha and Kufri Girdhari were able to produce mini-tubers albeit with different efficiencies distinctly showing the effect of micro-tuber size and genotypes (Srivastava et al., 2015).

Hence in the present investigation, an attempt was made to evaluate the effect of different dormancy breaking growth regulators and their dip duration on different grades of microtubers for growth and yield parameters under aphid proof net house conditions of central India.

\section{MATERIALS AND METHODS}

The experiment was conducted at Central Potato Research Station, Gwalior (latitude of $26^{0} \mathrm{~N}, 78^{0} \mathrm{E}$ ) during 2012-13. 20 micro-tubers of three different size $>4$ $-6 \mathrm{~mm},>6-8 \mathrm{~mm}$ and $>8 \mathrm{~mm}$ of variety Kufri Sindhuri were given dip treatment with six types of growth regulators/ dormancy breaking chemicals viz 1ppm gibberelic acid, $0.5 \mathrm{ppm}$ gibberllic acid, $1 \%$ thiourea, 0.5 $\%$ thiourea, $1 \mathrm{ppm}$ gibberllic acid $+1 \%$ thiourea and $0.5 \mathrm{ppm}$ gibberllic acid $+0.5 \%$ thiourea along with water control for $30 \mathrm{~min}, 45 \mathrm{~min}$ and $60 \mathrm{~min}$. After dip treatment microtubers were planted in insect proof net house. The above said seed material was planted at 30 $\mathrm{x} 10 \mathrm{~cm}$ spacing in $2 \mathrm{~m}$ rows $\left(0.6 \mathrm{M}^{2}\right.$ plot size $)$ during second week of November. The experiment was planted in split plot design and replicated three times. A light irrigation was given with the help of shower just after planting and subsequent irrigation was given after 10-12 days interval as per the need of the crop. Other packages of practices were followed as per the recommendation of seed potato crop. Data were pooled and analyzed statistically and means were separated according to the least significant differences (LSD) at 0.05 level of probability.

\section{RESULTS AND DISCUSSION}

Growth parameters: Emergence was significantly higher in all the dormancy breaking chemicals over water control $(58.15 \%)$ and highest was recorded in $0.5 \%$ GA treatment (75.74\%). $30 \mathrm{~min}$ dip duration showed non-significantly higher emergence $(71.59 \%)$ over 45 and $60 \mathrm{~min}$ duration. $>6-8 \mathrm{~mm}$ size $(78.73 \%)$ and $>8 \mathrm{~mm}$ size $(69.68 \%)$ microtubers recorded significantly higher emergence at $5 \%$ level over $>4 \mathrm{~mm}$ size microtubers $(59.52 \%)$ (Table 1$)$. The micro-tuber survival was very good for the bigger sized micro-tubers i.e. in the grade of 4-8 $\mathrm{mm}$ and $>8 \mathrm{~mm}$ for both Kufri Girdhari and Kufri Megha (>90\%). Microtuber emergence was showed decreasing trend with decrease size

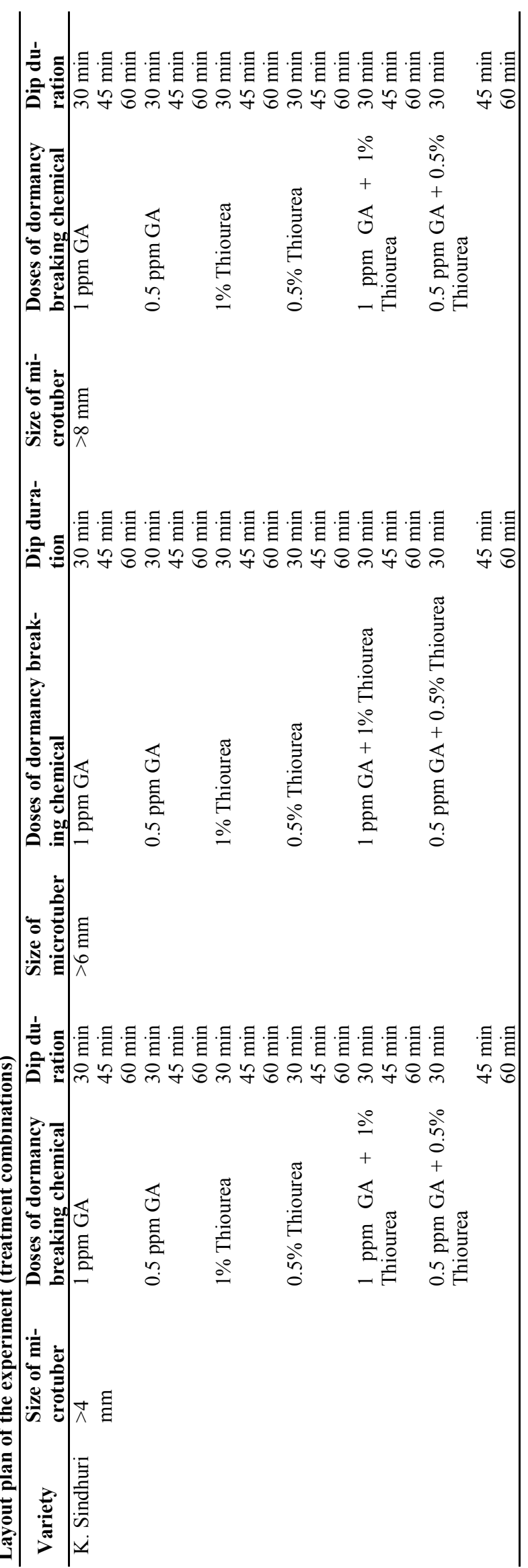


Table 1. Potato micro-tubers growth parameters as influenced by dormancy breaking chemicals, dip duration and microtuber size.

\begin{tabular}{|c|c|c|c|c|c|c|c|}
\hline \multirow{3}{*}{$\begin{array}{l}\text { Growth regulator/Dip duration/Tuber } \\
\text { size }\end{array}$} & \multicolumn{7}{|c|}{ Growth parameters } \\
\hline & \multirow{2}{*}{$\begin{array}{c}\text { Emer- } \\
\text { gence \% }\end{array}$} & \multicolumn{2}{|c|}{ Plant height (cm) } & \multicolumn{2}{|c|}{ No. of stem } & \multicolumn{2}{|c|}{$\begin{array}{c}\text { No of Compound } \\
\text { leaves }\end{array}$} \\
\hline & & 50 DAP & 75DAP & 50 DAP & 75DAP & 50 DAP & 75DAP \\
\hline Water control & 58.15 & 7.6 & 47.7 & 1.2 & 1.2 & 8.8 & 18.6 \\
\hline 1ppm gibberllic acid & 71.30 & 8.0 & 51.3 & 1.4 & 1.4 & 11.9 & 21.4 \\
\hline $0.5 \mathrm{ppm}$ gibberllic acid & 75.74 & 8.3 & 49.7 & 1.5 & 1.5 & 11.0 & 21.5 \\
\hline $1 \%$ Thiourea & 73.70 & 7.9 & 57.4 & 1.4 & 1.2 & 11.0 & 22.0 \\
\hline $0.5 \%$ Thiourea & 64.26 & 7.4 & 56.4 & 1.3 & 1.3 & 9.4 & 20.1 \\
\hline $1 \mathrm{ppm}$ gibberllic acid $+1 \%$ thiourea & 72.22 & 8.1 & 55.7 & 1.8 & 1.4 & 12.1 & 20.7 \\
\hline $0.5 \mathrm{ppm}$ gibberllic acid $+0.5 \%$ thiourea & 70.74 & 9.4 & 55.2 & 1.4 & 1.4 & 10.0 & 20.5 \\
\hline $\operatorname{SEm}( \pm)$ & 1.83 & 0.18 & 0.68 & 0.09 & 0.29 & 0.69 & 0.72 \\
\hline $\mathrm{CD}$ & 5.62 & 0.57 & 2.11 & 0.29 & NS & 2.13 & NS \\
\hline $30 \mathrm{~min}$ & 71.59 & 7.7 & 54.2 & 1.5 & 1.4 & 10.5 & 21.2 \\
\hline $45 \mathrm{~min}$ & 68.18 & 8.2 & 52.3 & 1.4 & 1.4 & 10.5 & 21.0 \\
\hline $60 \mathrm{~min}$ & 68.57 & 8.4 & 53.5 & 1.5 & 1.3 & 10.8 & 19.9 \\
\hline $\operatorname{SEm}( \pm)$ & 1.20 & 0.24 & 0.68 & 0.06 & 0.04 & 0.35 & 0.45 \\
\hline $\mathrm{CD}$ & NS & NS & NS & NS & NS & NS & NS \\
\hline$>4 \mathrm{~mm}$ & 59.92 & 5.1 & 45.8 & 1.2 & 1.1 & 7.0 & 17.7 \\
\hline$>6-8 \mathrm{~mm}$ & 78.73 & 8.1 & 54.5 & 1.3 & 1.2 & 9.7 & 18.8 \\
\hline$>8 \mathrm{~mm}$ & 69.68 & 11.1 & 59.7 & 1.9 & 1.7 & 15.1 & 25.6 \\
\hline $\operatorname{SEm}( \pm)$ & 1.20 & 0.24 & 0.58 & 0.06 & 0.04 & 0.35 & 0.45 \\
\hline $\mathrm{CD}$ & 3.36 & 0.66 & 1.61 & 0.15 & 0.11 & 0.98 & 1.27 \\
\hline SEm $( \pm)$ Growth regulator $x$ Dip duration & 3.17 & 0.62 & 1.52 & 0.15 & 0.10 & 0.92 & 1.20 \\
\hline CD Growth regulator $\mathrm{x}$ Dip duration & 8.89 & 1.75 & 4.26 & 0.41 & $\mathrm{NS}$ & 2.59 & 3.37 \\
\hline SEm $( \pm)$ Growth regulator $x$ Microtuber size & 3.17 & 0.62 & 1.52 & 0.15 & 0.15 & 0.92 & 1.20 \\
\hline CD Growth regulator $\mathrm{x}$ Microtuber size & 8.88 & 1.75 & NS & 0.41 & NS & 2.59 & 3.37 \\
\hline SEm $( \pm)$ Dip Duration x Microtuber size & 2.08 & 0.41 & 1.00 & 0.10 & 0.07 & 0.61 & 0.79 \\
\hline CD Dip Duration $x$ Microtuber size & NS & NS & 2.79 & NS & 0.19 & NS & 2.21 \\
\hline $\begin{array}{l}\text { SEm }( \pm) \text { Growth regulator } x \text { Dip Duration } x \\
\text { Microtuber size }\end{array}$ & 5.49 & 1.08 & 2.64 & 0.25 & 0.18 & 1.60 & 2.08 \\
\hline $\begin{array}{l}\text { CD Growth regulator x Dip Duration x Mi- } \\
\text { crotuber size }\end{array}$ & NS & 3.03 & NS & NS & 0.50 & 4.48 & 5.83 \\
\hline
\end{tabular}

$97 \%$ in $3-5 \mathrm{~g}$ and lowest $82.0 \%$ in $0.3-0.5 \mathrm{~g}$ microtubers (Kawakami and Iwama, 2012). As the size grade decreases to $<4 \mathrm{~mm}$, the potential of the micro-tuber survival decreased significantly (79.4\%) Srivastava et al. (2015). Désiré et al. (1995) The growth and surviv$\mathrm{al} /$ vigor of potato tubers is supported by the food material stored in the tubers particularly carbohydrates and could thus be conducive to plant development and hence relatively bigger micro-tubers have distinct advantage as far as emergence is concerned and confirms the present study. Present findings are also in agreement with Somani and Venkatasalam (2012) who reported the role of both size and genotype on microtuber emergence (\%) and survival where emergence per cent of microtubers ranged from 27.4 (Kufri Kanchan) to 73.6 (Kufri Lauvkar) with an overall average of 64.6\%. Cultivar Kufri Lauvkar (73.6\%) resulted maximum emergence where the average weight of microtubers planted was highest $(0.13 \mathrm{~g})$ and minimum in Kufri Kanchan (27.4\%) with average weight of microtubers planted was $0.08 \mathrm{~g}$. Only $46 \%$ of microtubers with $<3 \mathrm{~mm}$ diameter are able to sprout, while this amount for microtubers with $3-5 \mathrm{~mm}$ and $>$ $5 \mathrm{~mm}$ diameter was $75 \%$ and $98 \%$ respectively (Bolandi et al., 2011). Alsadon et al (1988) reported that functionality of plants glands produced by small micro tubers is less than larger microtubers. Larger sizes give better emergence and a better early vigour, and produce a higher yield and more tubers per plant (Struik and Wiersema, 1999).

Plant height at 50 days after planting was significantly higher in $0.5 \mathrm{ppm}$ gibberllic acid $+0.5 \%$ thiourea treatment $(9.4 \mathrm{~cm})$ followed by $0.5 \mathrm{ppm}$ gibberllic acid $(8.3 \mathrm{~cm})$ over water control $(7.6 \mathrm{~cm})$. No significant difference was recorded in dip duration. Plant height was significantly lowest in $>4 \mathrm{~mm}$ size microtubers $(5.1 \mathrm{~cm})$ over $>6-8 \mathrm{~mm}$ size $(8.1 \mathrm{~cm})$ and $>8 \mathrm{~mm}$ size microtubers $(11.1 \mathrm{~cm})$ at 50 days after planting. Increase in plant height with increase in microtuber size is due higher vigour in the microtuber of large size. At 75 days after planting, all the growth regulator treatment were significantly higher at 5\% level over water control $(47.7 \mathrm{~cm})$ table 1 . There was increase in plant height with increase in the $\mathrm{GA}_{3}$ doses from 0 to 160 ppm in variety Morphona (Shekari et al., 2010). No significant difference was recorded in dip duration. Plant height was significantly lower in $>4 \mathrm{~mm}$ size microtubers $(48.8 \mathrm{~cm})$ than $>6-8 \mathrm{~mm}$ size $(54.5 \mathrm{~cm})$ and 
Table 2. Potato micro-tubers yield parameters as influenced by dormancy breaking chemicals, dip duration and microtuber size.

\begin{tabular}{|c|c|c|c|c|c|c|}
\hline \multirow{3}{*}{ Growth Regulator/Dip duration/Tuber size } & \multicolumn{6}{|c|}{ Yield parameters } \\
\hline & \multicolumn{2}{|c|}{ Yield/plant } & \multicolumn{2}{|c|}{$<3$ g Yield/ha } & \multirow{2}{*}{$\begin{array}{c}\text { Total } \\
\text { No } \\
(000 / \mathbf{h a}) \\
\end{array}$} & \multirow{2}{*}{$\begin{array}{c}\text { yield/h } \\
\text { Weight (q/ } \\
\text { ha) }\end{array}$} \\
\hline & $\begin{array}{c}\text { No (000/ } \\
\text { ha) }\end{array}$ & $\begin{array}{c}\text { Weight } \\
(\mathrm{Kg})\end{array}$ & $\begin{array}{c}\text { No (000/ } \\
\text { ha) }\end{array}$ & $\begin{array}{l}\text { Weight } \\
\text { (q/ha) }\end{array}$ & & \\
\hline Water control & 18 & 0.15 & 967 & 18.33 & 2067 & 181.67 \\
\hline 1ppm gibberllic acid & 19 & 0.19 & 1100 & 20.00 & 2350 & 218.33 \\
\hline $0.5 \mathrm{ppm}$ gibberllic acid & 23 & 0.18 & 1183 & 20.00 & 2500 & 205.00 \\
\hline $1 \%$ Thiourea & 21 & 0.19 & 1083 & 20.00 & 2350 & 208.33 \\
\hline $0.5 \%$ Thiourea & 19 & 0.20 & 967 & 20.00 & 2150 & 203.33 \\
\hline 1ppm gibberllic acid $+1 \%$ thiourea & 20 & 0.15 & 1450 & 25.00 & 2667 & 196.67 \\
\hline $0.5 \mathrm{ppm}$ gibberllic acid $+0.5 \%$ thiourea & 21 & 0.21 & 1183 & 20.00 & 2467 & 226.67 \\
\hline $\operatorname{SEm}( \pm)$ & 1.2 & 0.012 & 38 & 0.83 & 48 & 8.50 \\
\hline $\mathrm{CD}$ & NS & 0.036 & 118 & 2.67 & 148 & 26.00 \\
\hline $30 \mathrm{~min}$ & 21 & 0.18 & 1150 & 20.00 & 2500 & 206.67 \\
\hline $45 \mathrm{~min}$ & 22 & 0.18 & 1133 & 21.67 & 2367 & 210.00 \\
\hline $60 \mathrm{~min}$ & 19 & 0.19 & 1117 & 20.00 & 2233 & 201.67 \\
\hline $\operatorname{SEm}( \pm)$ & 0.9 & 0.008 & 38 & 0.83 & 52 & 5.00 \\
\hline $\mathrm{CD}$ & NS & NS & NS & NS & 143 & NS \\
\hline$>4 \mathrm{~mm}$ & 16 & 0.11 & 983 & 15.00 & 1850 & 113.33 \\
\hline$>6-8 \mathrm{~mm}$ & 19 & 0.19 & 1150 & 21.67 & 2417 & 208.33 \\
\hline$>8 \mathrm{~mm}$ & 26 & 0.25 & 1267 & 23.33 & 2833 & 295.00 \\
\hline $\operatorname{SEm}( \pm)$ & 0.9 & 0.008 & 38 & 0.83 & 52 & 5.00 \\
\hline $\mathrm{CD}$ & 2.5 & 0.022 & 108 & 2.50 & 143 & 14.17 \\
\hline SEm $( \pm)$ Growth regulator $x$ Dip duration & 2.3 & 0.021 & 102 & 2.33 & 135 & 13.33 \\
\hline CD Growth regulator $\mathrm{x}$ Dip duration & NS & 0.059 & NS & NS & NS & 37.33 \\
\hline SEm $( \pm)$ Growth regulator $x$ Microtuber size & 2.3 & 2.3 & 102 & 2.33 & 135 & 13.33 \\
\hline CD Growth regulator $\mathrm{x}$ Microtuber $\mathrm{r}$ size & NS & 0.059 & 287 & 6.50 & 380 & 37.33 \\
\hline SEm ( \pm ) Dip Duration x Microtuber size & 1.5 & 0.014 & 67 & 1.50 & 88 & 8.67 \\
\hline CD Dip Duration x Microtuber size & NS & NS & NS & NS & NS & NS \\
\hline $\begin{array}{l}\text { SEm }( \pm) \text { Growth regulator x Dip Duration x Mi- } \\
\text { crotuber size }\end{array}$ & 4.1 & 0.037 & 177 & 4.00 & 235 & 23.17 \\
\hline $\begin{array}{l}\text { CD Growth regulator x Dip Duration x Microtuber } \\
\text { size }\end{array}$ & NS & NS & NS & NS & NS & NS \\
\hline
\end{tabular}

$>8 \mathrm{~mm}$ size microtubers $(59.7 \mathrm{~cm})$ at 75 days after planting. Increase in micro-tuber size from $<4 \mathrm{~mm}$ to $>8 \mathrm{~mm}$ size there was a corresponding increase in plant height when reported after 60 days after planting (Srivastava et al., 2015). This confirms the present findings of increase in plant height with increase in tuber size.

Number of stem /plant at 50 days after planting were significantly higher in $1 \mathrm{ppm}$ gibberllic acid $+1 \%$ thiourea (1.8) followed by $0.5 \mathrm{ppm}$ gibberllic acid (1.5) over water control (1.2). No significant difference was recorded in dip duration. Significantly higher stem/ plant was recorded $>8 \mathrm{~mm}$ size microtubers (1.9) followed by $>6-8 \mathrm{~mm}$ size (1.3) over $>4 \mathrm{~mm}$ size microtubers (1.2). At 75 days after planting, no significant differences were recorded among growth regulators and dip duration. Significantly higher stem/plant was recorded $>8 \mathrm{~mm}$ size microtubers (1.7) followed by $>6$ $8 \mathrm{~mm}$ size (1.2) over $>4 \mathrm{~mm}$ size microtubers (1.1) table 1 . Present findings are also in agreement with Srivastava et al. (2015) who reported that larger sized micro-tubers $(>8 \mathrm{~mm}$ and $4-8 \mathrm{~mm}$ ) did not exhibited significant $(\alpha=5 \%)$ difference in terms of stems/plant but were superior to those in the smallest size microtuber $(<4 \mathrm{~mm})$.

Number of compound leaves/plant at 50 days after planting were significantly higher at $5 \%$ level in $1 \mathrm{ppm}$ gibberllic acid $+1 \%$ thiourea (12.1) followed by $1 \mathrm{ppm}$ gibberllic acid (11.9) over water control (8.8). No significant difference was recorded in dip duration. Significantly higher number of compound leaves/plant was recorded $>8 \mathrm{~mm}$ size microtubers (15.1) followed by $>6-8 \mathrm{~mm}$ size $(9.7)$ over $>4 \mathrm{~mm}$ size microtubers (7.0). At 75 DAP no significant differences were recorded among growth regulators and dip duration. Significantly higher number of compound leaves/plant was recorded $>8 \mathrm{~mm}$ size microtubers (25.6) followed by $>6-8 \mathrm{~mm}$ size $(18.8)$ over $>4 \mathrm{~mm}$ size microtubers (17.7) table1. The number of leaves/plant followed similar pattern to plant height. As the micro-tuber size increased, the number of leaves/plant also significantly increased from 39 in $<4 \mathrm{~mm}$ to $47.5 \mathrm{in}>8 \mathrm{~mm}$ microtuber size (Srivastava et al., 2015). Similar pattern among plant height and number of leaves/plant was expected due to the fact that increase in plant height may result due to an increase in the number of nodes leading to increased number of leaves/plant. A smaller LAI was observed in plants from small microtubers than from large microtubers at the beginning of the growing season, and no difference was observed in Leaf area index after the start of flowering about 30 days after emergence (Kawakami et al.2006; Kawaka- 
mi and Iwama 2012). The initial smaller LAI in the plants from small microtuber suggests that a narrow planting distance could decrease the initial difference in LAI among plants grown from seed tuber of small size (Kawakami and Iwama, 2012).

Yield parameters: Non-significantly higher tuber number/plant were recorded in all the treatments over water control and highest was recorded in $0.5 \mathrm{ppm}$ gibberllic acid treatment (23). The average number of tubers per plant was greatest in the $\mathrm{GA}_{3}$ treatment (3.6); almost double that of other treatments that were not different from the control (Habib, 1999). GA 3 application significantly influenced tuber number per plant. $\mathrm{GA}_{3}$ increased the mean tuber number per plant from 4 in control to 7.5 at 160 ppm $\mathrm{GA}_{3}$ application (Shekari et al., 2010). In dip durations there were nonsignificant difference. Significantly higher tuber number were recorded in $>8 \mathrm{~mm}$ size microtubers (26) followed by $>6-8 \mathrm{~mm}$ size (19) over $>4 \mathrm{~mm}$ size microtubers (16). Significantly higher tuber weight was recorded in all the treatments except 1ppm gibberllic ac$\mathrm{id}+1 \%$ thiourea over control $(0.15 \mathrm{~kg})$ table 2 . Treatment with $\mathrm{GA}_{3}$ (1000 ppm for 1 hour) yielded highest tuber number/plant (Rehman et al, 2001). Mani et al (2013) reported that applying at least $250 \mathrm{mM}$ solution of thiourea increased yield up to $810 \mathrm{~g} / \mathrm{plant}$, which equivalent to $28 \mathrm{t} / \mathrm{ha}$. This value is significantly superior over control (630 g/plant). No significant difference was recorded in dip duration. Significantly higher weight of tuber/plant was recorded $>8 \mathrm{~mm}$ size microtubers $(0.25 \mathrm{~kg})$ followed by $>6-8 \mathrm{~mm}$ size $(0.19 \mathrm{~kg})$ over $>4 \mathrm{~mm}$ size microtubers $(0.11 \mathrm{~kg})$. There is a direct and significant relationship between used microtuber size and weight and number of produced minitubers in each plant, so that total weight of produced minituber by each plant which is produced from microtubers $<5 \mathrm{~mm}$ is $29.48 \mathrm{~g}$ and for microtubers $>10 \mathrm{~mm}$ is $49.08 \mathrm{~g}$ (Bolandi et al. 2011). This confirms the present study and indicates that higher size of microtuber yields more than smaller one.

There is general tendency of production $<3 \mathrm{~g}$ minitubers from microtubers/ microplants. In the present study, significantly higher tuber number/ha was recorded in all the treatment except $0.5 \%$ thiourea over water control (967 thousand/ha) and highest was recorded in $1 \mathrm{ppm}$ gibberllic acid $+1 \%$ thiourea (1450 thousand/ha). No significant difference was recorded in dip duration. Significantly higher $<3 \mathrm{~g}$ tuber number/ ha were recorded in $>8 \mathrm{~mm}$ size microtubers (1267 thousand) followed by $>6-8 \mathrm{~mm}$ size (1150 thousand) over $>4 \mathrm{~mm}$ size microtubers (983 thousand). For weight, only $1 \mathrm{ppm}$ gibberllic acid $+1 \%$ thiourea $(25 \mathrm{q} /$ ha) recorded significantly higher $<3 \mathrm{~g}$ tuber weight. No significant difference was recorded in dip duration. Significantly higher $<3 \mathrm{~g}$ tuber weight $(\mathrm{q} / \mathrm{ha}$ ) were recorded in $>8 \mathrm{~mm}$ size microtubers (23.33) followed by $>6-8 \mathrm{~mm}$ size (21.67) over $>4 \mathrm{~mm}$ size microtubers
(15.00) table 2. Srivastava et al., (2015) reported that the small sized micro-tubers $(<4 \mathrm{~mm})$ produced relatively less number of small sized tubers per plant as compared to the larger sized micro-tubers (4-8 $\mathrm{mm}$ and $>8 \mathrm{~mm}$ ). Thus maximum yield per plant was produced by $>8 \mathrm{~mm}$ grade micro-tubers followed by 4-8 $\mathrm{mm}$ and $<4 \mathrm{~mm}$ grade micro-tubers. Similar yield pattern was observed for number of tubers $/ \mathrm{m} 2$ and yield/ $\mathrm{m} 2$. The difference for tuber size distribution can be influenced by the micro-tuber size as well as the genotype (Ranalli et al. 1994). Total yield variation may also be accounted to the initial growth and survival rate at the time of planting (Kumar et al., 2007).

Significantly higher tuber number (thousand/ha) was recorded in all the treatment except $0.5 \%$ thiourea over water control (2067 thousand) and highest was recorded in $1 \mathrm{ppm}$ gibberllic acid $+1 \%$ thiourea (2667 thousand) table $2 . \mathrm{GA}_{3}$ was the most active compound for early as well as multiple sprouting; it produced the highest number of tubers with lowest total fresh weight compared with the other treatments (Habib, 1999). Among dip durations, $30 \mathrm{~min}$ dip treatment (2500 thousand) recorded significantly higher tuber number (thousand/ha) over $60 \mathrm{~min}$ dip treatment $(2233$ thousand). Significantly higher tuber number (thousand/ha) were recorded in $>8 \mathrm{~mm}$ size microtubers ( 2833 thousand) followed by $>6-8 \mathrm{~mm}$ size $(2417$ thousand) over $>4 \mathrm{~mm}$ size microtubers (1850 thousand).

Significantly higher tuber yield (q/ha) was recorded in 1ppm gibberllic acid (218.33q) and $0.5 \mathrm{ppm}$ gibberllic acid $+0.5 \%$ Thiourea $(226.67 \mathrm{q})$ over control (181.67 q). Mani et al. (2013) reported that application of 250 $\mathrm{mM}$ of thiourea excelled over other doses for growth plant parameters, tuber yield and quality attributes. It gives an increase in yield of $26 \%$ with tubers rich in starch and in soluble proteins due to an increase in total sugars and sucrose measured in growing leaves of treated plants. No significant difference was recorded in dip duration. Significantly higher weight of tuber (q/ ha) was recorded $>8 \mathrm{~mm}$ size microtubers ( $295 \mathrm{q})$ followed by $>6-8 \mathrm{~mm}$ size (208.33 q) over $>4 \mathrm{~mm}$ size microtubers $(113.33 \mathrm{q})$ table 2 . Minitubers functionality was increased by microtubers size and reaches to 20, 27 and 40 tons/ha for microtubers with $<3 \mathrm{~mm}, 3$ $5 \mathrm{~mm}$ and $>5 \mathrm{~mm}$ diameter (Bolandi et al., 2011). No significant difference in fresh or dry tuber yield was observed among the MT classes, suggesting that the use of the MT of even $0.3 \mathrm{~g}$ may be a feasible practice under the field condition. The tuber fresh yield of about 41 to $66 \mathrm{t}$ ha-1 observed in the plants from MT demonstrates the high yield potential of MT as seed tubers in the field, although the yearly variation in tuber yield was higher in plants from MT than in plants from CT (Kawakami and Iwama, 2012). According to Singh et al. (2001) the rate of micro-tuber multiplication increased with the increase in size. This 
confirms the present study where seed multiplication rate was 26 times in $>8 \mathrm{~mm}$ microtubers and 16 times in $<4 \mathrm{~mm}$ microtubers leading to the higher tuber number and yield than small sized tubers.

\section{Conclusion}

The present study concluded that potato micro-tubers can be used as initial planting material for nucleus seed production in potato. The micro-tubers of $>8 \mathrm{~mm}$ size treated with $0.5 \mathrm{ppm}$ gibberllic acid alone or in combination with $0.5 \%$ thiourea for $30 \mathrm{~min}$ resulted in higher growth and yield parameters. The minitubers produced from microtubers can be used for further multiplication for producing high quality seed material under G-1 and G-2 thereby helping in attaining selfsufficiency for seed potato.

\section{REFERENCES}

Alsadon, A.A., Knutson, K.W. and Wilkinson, J.C. (1988). Relationship between microtuber and minituber production and yield characteristics of six potato cultures. American potato J., 65:468

Badoni, A. and Chauhan, J. S. (2009). Microtuber: A Source of Germplasm Conservation, Report and Opinion., 1(3): 69-71

Bolandi,A. R., Hamidi, H.and Ghavidel, R.A.(2011).The Effects of Size and Microtuber Dormancy on Production of Potato Minitubers. American-Eurasian Journal of Agriculture \& Environment Science. 10 (2): 169-173

Désiré, S., Couillerot, J.P., Hilbert, J.L. and Vasseur J. (1995) Dormance et germination des microtubercules de pomme de terre (Solanum tuberosum L.) produit in vitro: Effets de la concentration en saccharose du milieu de tubérisation, de la durée de conservation à $4^{\circ} \mathrm{C}$ et d'un traitement avec de l'acide gibbérellique. Acta Botanica Gallica, 142:371-378

Germchi, S., Khorshidi, B. M., HassanPanah, D., Yarnia, M. and Faramarzi, A. (2010). Effect of Thiourea on dormancy breaking and performance of Agria minitubers in green house and laoratory. Journal of New Agricultural Science., 18(6):65-72

Habib, A. (1999). Micro-tuberization and dormancy breaking in potato (Solanum tuberosum L.). MSc thesis. McGill University, Department of Plant Science, Quebec, Canada

HassanPanah,D., Shahryari, R., Shamel, A. and Fathi, L. (2007). Effect of thiourea and GA on Agria's mini tuber dormancy breaking. Proceeding of $5^{\text {th }}$ Iranian Horticultural science research Center. Shiraz University, 1-4 sep. Shiraz, Iran., p 100

Kawakami, J. and Iwama, K.(2012). Effect of potato microtuber size on the growth and yield performance of field grown plants. Plant Production Science., 15(2):144-148

Kawakami, J., Iwama, K. and Jitsuyama, Y.(2006). Soil water stress and the growth and yield of potato plants grown from microtubers and conventional seed tubers. Field Crops Research.,20:237-250

Kumar, D., Singh, V., Singh, R.P., Singh, B.P. and Naik,
P.S.(2007). Performance of in-vitro plantlets for production of mini-tubers in vector free environment. Potato Journal.,34:131-132

Mani, F., Bettaieb, T., Zheni, K., Doudech, N. and Hannachi, C.(2013). Effect of Thiourea on Yield and Quality of Potato (Solanum tuberosum L.) Journal of stress physiology \&biochemistry.,9 (1): 88-95

Otroshy,M. and Struik, P. C.(2006). Utilization of tissue culture techniques in a seed potato tuber production scheme. $\mathrm{PhD}$ Thesis, Wageningen University, Wageningen, the Netherlands, $264 \mathrm{pp}$

Panah, D., Shahryari, R., Shamel, A. and Fathi, L. (2007). Effect of thiourea and GA on Agria's mini tuber dormancy breaking. Proceeding of $5^{\text {th }}$ Iranian Horticultural science research Center. Shiraz University, 1-4 sep. Shiraz, Iran.p 100

Ranalli, P., Bassi, F., Ruaro, G., Del Re ,P., Di Candilo, M. and Mandolino, G.(1994). Micro-tuber and mini-tuber production and field performance compared with normal tubers. Potato Research.,37:383-391

Rehman, F., Lee, S. K., Kim, H. S., Jeon, H.S., Park, J.H. and Joung, J.H. (2011). Dormancy breaking and effect on tuber yield on potato subjected to various chemicals and growth regulators in potato. Online journal of biological sciences, 1(9):818-820

Shekari, F., Benam, M.B.K., Germchi, S. and Hassanpanah, D. (2010). Effect of GA3 on dormancy breaking of 'Marfona' potato mini-tubers under greenhouse conditions. Journal of Food, Agriculture \& Environment., 8 (3\& 4):422-425

Singh, D.B., Chaubey, I.P. and Singh, S.(2001). Rapid Seed multiplication in potatoes through micro-tubers. Journal of Indian Potato Association., 28: 103-04

Somani, A.K. and Venkatasalam, E.P. (2012). Microtuber propagation for breeder's seed production of potato. Potato Journal.,39 (1): 98-100.

Srivastava, A. K., Yadav, S. K., Diengdoh, L. C., Rai, R. and Bag,T. K.(2015). Effect of cultivars and seed size on field performance of potato micro-tubers in North Eastern Himalayan region in India. Journal of Applied and Natural Science., 7(1): $335-338$

Struik, P.C. and Wiersema, S.G. (1999). Seed Potato Technology. Wageningen Pers, Wageningen, The Netherlands, pp: 383

Venkatasalam, E.P., Latawa, J., Sharma, S., Sharma,S., Sharma, A.K., Sharma, S., Patial, R. and Singh, S. (2011). In vitro and in vivo performance of potato cultivars for different seed production systems. Potato Journal.,38 (2): 149-154

Park, S.W., Jeon, J.H., Kim, H.S., Hong, S.J., Aswath, C. and Joung, H. (2009). The effect of size and quality of potato microtubers on quality of seed potatoes in the cultivar 'Superior'. Scientia Horticulturae 120 (1) 3: $127-129$

Hossain, M. S., Hossain M.M, Haque, M.M., Haque, M.M. and Sarkar, M.D. (2017). Varietal Evaluation of Potato Microtuber and Plantlet in Seed Tuber Production. International Journal of Agronomy. https:// doi.org/10.1155/2017/7520297 